\title{
Interpretation QS. an-Nisa': 34 Perspectives of Amina Wadud Muhsin and The Implication of Her Thinking In Indonesia
}

\author{
Naili Rosa Urbah Rusydiana, Hadiana Trendi Azami \\ Universitas Islam Negeri Sunan Kalijaga Yogyakarta, Indonesia \\ nailirosa4700gmail.com
}

\begin{tabular}{c} 
Article \\
Information \\
\hline
\end{tabular}

Received: August 13, 2021

Revised 1: February 6, 2021

Revised 2: June 26, 2021

Accepted: July 21, 2021

Keywords

Hermeneutics, Gender, Interpretation of Feminism
Kata Kunci

Hermeneutika, Gender, Tafsir Feminisme

\section{Abstract}

This paper describes the gender verse that has become a hot discourse during groups that interpret religious texts as misogynistic. One of them is in QS. an-Nisa': 34 concerning the position of men against women. The majority of classical commentators interpret this verse textually that men are more powerful than women. However, in this contemporary era, many figures reconstruct this interpretation. One of them is Amina Wadud. Through this paper, the writer tries to reconstruct the interpretation of QS. an-Nisa': 34 with the method of Hermeneutics Tauhid Amina Wadud. As a result, first, the word "ar-rijalu qawwamuna 'ala nisa" cannot only be interpreted as a husband and wife. This word applies to two situations that occur. The first situation is the right to take precedence over others and provide a living for women. However, if one of these conditions is nowhere, then the man is considered a failure and is not included in the qawwam meant for women. Second, the word nusyuz does not only apply to women but also men. Third, the implications of Amina Wadud's thought in Indonesia can be measured through: the intensity of being a resource at Indonesian conferences, the spread of her work and many studies on her thoughts, either critical studies or using them as a methodological basis, and many researchers who are inspired or have the same mindset as.

\section{Abstrak}

Tulisan ini menguraikan ayat gender yang menjadi perbincangan dan menjadi diskursus yang sedang hangat-hangatnya, di tengah pandangan kelompok yang menafsirkan teks keagamaan secara misoginis. Salah satunya terdapat pada QS. an-Nisa': 34 tentang kedudukan laki-laki atas perempuan. Mayoritas penafsiran klasik menafsirkan ayat ini secara tekstual dimaknai dengan anggapan laki-laki lebih berkuasa 
atas perempuan. Akan tetapi, di zaman kontemporer sekarang banyak tokoh yang merekonstruksi penafsiran tersebut, salah satunya Amina Wadud. Melalui tulisan ini penulis berusaha merekontruksi penafsiran QS. an-Nisa': 34 dengan metode Hermeneutika Tauhid Amina Wadud. Hasilnya, pertama, kata "ar-rijaluqawwamuna 'ala nisa"” ini tidak cukup apabila hanya diartikan sebagai sepasang suami istri saja. Kata ini berlaku apabila terdapat dua keadaan yang berlangsung. Keadaan pertama hak untuk didahulukan daripada yang lain dan memberikan nafkah harta kepada perempuan. Namun, apabila salah satu keadaan tersebut tidak terlaksana, menyebabkan laki-laki dianggap gagal, dan tidak termasuk qawwam yang dimaksud atas perempuan. Kedua, kata nusyuz tidak hanya berlaku bagi wanita saja, akan tetapi juga berlaku bagi laki-laki. Ketiga, implikasi pemikiran Amina Wadud di Indonesia dapat diukur melalui: intensitas menjadi narasumber konferensi di Indonesia, penyebaran karya dan banyaknya kajian terhadap pemikirannya, baik studi kritis atau menjadikannya sebagai landasan metodologis, dan banyaknya peneliti yang terinspirasi atau memiliki pola pikir sama dengan Amina Wadud

\section{Introduction}

Today, gender interpretation is becoming a hot topic amidst groups that understand religious texts as a misogynist. One of them is in QS. an-Nisa': 34 about the position of men more power over women. The scholars who interpret this verse that women should not be leaders are Ibn Qudâmah ${ }^{1}$ and Yusuf al-Qardhawi. ${ }^{2}$ Some scholars who disagree with the thoughts of Ibn Qudâmah and Yusuf al-Qardhawi are Amina Wadud ${ }^{3}$ and M.

\footnotetext{
${ }^{1}$ Ali Syahbana, "Studi Komparatif Pemikiran Ibnu Hazm Dan Ibnu Qudamah Tentang Hukum Penyusuan (Raḍā 'ah)” (PhD Thesis, IAIN Palangka Raya, 2018), 58-59.

${ }^{2}$ Yusuf Qardhawi asserts that "Men are leaders for women", this affirmation from QS. an-Nisa': 34, where the aspect of male leadership is related to home life, and not in government. Furthermore, al-Qardhawi asserted that the status of women's leadership in Islamic politics is only briefly interpreted. One of the conditions of becoming a leader is amirul mu'minin which is (male) al-rijal, meaning that women cannot be leaders, or imams. Al-Qardhawi always attributed his thinking based on the events that occurred at the time, he did not see contextually. See in Muhammad Zainudin and Ismail Maisaroh, "Posisi Wanita Dalam Sistem Politik Islam," MIMBAR: Jurnal Sosial Dan Pembangunan 21, no. 2 (2005): 178-95.

${ }^{3}$ Abd Warits, "Menggagas Fiqh Perempuan: Membangun Kekuatan Hukum Bagi Perempuan (Telaah Kritis Atas Pemikiran Kh. Husein Muhammad)," in Proceedings of Annual Conference for Muslim Scholars, 2017, 486-503.
}

Quraish Shihab. ${ }^{4}$

Patriarchal culture in Indonesian society is the more powerful culture, especially among the traditional generation who hold the local culture closely. One of patriarchal culture with the determination of women's work is enough in three places: wells, mattresses, and kitchens. Impliedly want to tell that the existence of women is only limited to meet the needs of the head of the family. ${ }^{5}$ There is no denying that this is the fact of the past, especially during the Indonesian colonial period, further into the history of the Jahiliyyah Arabs, where women became the number two being, and their existence said to be a disgrace. ${ }^{6}$ Perhaps what exists today is a masculine interpretation rather than a feminist. Then, because of this situation, many women

\footnotetext{
${ }^{4}$ M. Quraish Shihab, Perempuan: Dari Cinta Sampai Seks, Dari Nikah Mut'ah Sampai Nikah Sunnah, Dari Bias Lama Sampai Bias Baru (Jakarta: Lentera Hati, 2010).

${ }^{5}$ Siti Komariah, "Perubahan Peranan Wanita Sunda: Studi Kasus Di Kota Bandung," TEMALI: Jurnal Pembangunan Sosial 2, no. 2 (2019): 354-84.

${ }^{6} \mathrm{R}$ Magdalena, "Kedudukan Perempuan Dalam Perjalanan Sejarah (Studi Tentang Kedudukan Perempuan Dalam Masyarakat Islam)," Harakat An-Nisa: Jurnal Studi Gender Dan Anak 2, no. 01 (2018).
} 
do not accept, so one of the ways that can finish as a form of disapproval is to construct an interpretation of the gender verse. ${ }^{7}$

In literature, studies on gender are classified into three, including socio-legal and political. Irsyadunnas conducted the study of gender social perspective. ${ }^{8}$ His research focuses more on the gender verses of Amina Wadud's perspective, such as human creation, female testimony. He suggested that the sanctity of males and women as equal in its creation. The concept offered is the relationship of the position of women and men in public life in general. In Haikal and Khozainul's study, ${ }^{9}$ they said that women who are entitled to polygamy are orphans as the purpose of the verse is to regulate the child's property to be adequately managed. ${ }^{10}$ At the same time, Rini contextualizes feminist interpretation to harmony between people, especially the household. ${ }^{11}$

Gender studies in the political sphere have been conducted by Arsal, ${ }^{12}$ Tri Marhaeni, ${ }^{13}$ Very, ${ }^{14}$ Zamroni. ${ }^{15}$ In Arsal's study, the position of men over women as stated in QS. an-Nisa': 34 cannot be interpreted in literacy alone which often makes gender bias. He dissected the verse with Amina Wadud's interpretation, the result being that women can be leaders both domestically and politically as long as they are within certain boundaries and do not exceed their nature as

\footnotetext{
${ }^{7}$ Abd Warits, "Menggagas Fiqh Perempuan."

${ }^{8}$ Irsyadunnas, "Tafsir Ayat-Ayat Gender Ala Amina Wadud Perspektif Hermeneutika Gadamer," Musãwa Jurnal Studi Gender Dan Islam 14, no. 2 (2015): 123-42.

${ }^{9}$ Khozainul Ulum, "Amina Wadud Muhsin Dan Pemikirannya Tentang Poligami," Al Hikmah: Jurnal Studi Keislaman 7, no. 1 (2017).

${ }^{10}$ Ibid.

${ }^{11}$ Rini, "Kontekstualisasi Tafsir Feminis Amina Wadud Pada Masyarakat Islam Di Indonesia," FOKUS Jurnal Kajian Keislaman Dan Kemasyarakatan 4, no. 1 (2019): 67-90.

${ }^{12}$ Arsal, "Menangkap Pesan-Pesan Hukum Dalam AlQur'an (Alternatif Dan Solutif Penggunaan Metode Tafsir Kontekstual Dalam Menghadapi Kasus-Kasus Kontemporer)," ALHURRIYAH: Jurnal Hukum Islam 1, no. 1 (2016): 1-14.

${ }^{13}$ Tri Marhaeni Pudji, "Citra Perempuan Dalam Politik," Yinyang: Jurnal Studi Islam Gender Dan Anak 3, no. 1 (2008): 3-16.

${ }^{14}$ Very Wahyudi, "Peran Politik Perempuan Dalam Perspektif Gender," Politea: Jurnal Politik Islam 1, no. 1 (2018): 63-83.

${ }^{15}$ Mohammad Zamroni, "Perempuan Dalam Kajian Komunikasi Politik Dan Gender," Jurnal Dakwah 14, no. 1 (2013): 103-32.
}

women. ${ }^{16}$ Then, Very explain that women could be leaders in the political space. They can be competent with men. ${ }^{17}$

Tri Marhaeni explains that the role of women in political spaces is discriminated. Some factors that prevent women from appearing in the political space include patriarchy, family, social class, historical context, and electoral system, which are all interconnected. One of the efforts that can be taken to be free from these obstacles is to destruct the image of women in the political space with the help of institutions and electoral support so that the position of women and men is equal. ${ }^{18}$ Meanwhile, to find out the inhibition of women in access to political space can be seen from the number of participation, ease of access to political space, critical awareness, control, and welfare of female participants. ${ }^{19}$

Departing from previous studies, the authors see gender discussions as based on socio-legal and political aspects. The author sees a gap in the Education sector or the implications of his thinking in Indonesia. This gap attracted the author's attention and intended to deeply examine Amina Wadud's thoughts on male leaders for women with different content analyses and approaches. The primary source in this study is Wadud's book, and the secondary source is a previous study of her thinking. How biographies and backgrounds influence Amina Wadud's thinking, how interpretation of QS. an-Nisa': 34 perspectives of Amina Wadud, how the implications of Amina Wadud's thinking and study on gender equality discourse are seen from the spread of books, visits to Indonesia, and the many studies on her thinking. This study will be using the hermeneutic perspective of tawhid.

\footnotetext{
${ }^{16}$ Arsal, "Menangkap Pesan-Pesan Hukum Dalam Al-Qur'an (Alternatif Dan Solutif Penggunaan Metode Tafsir Kontekstual Dalam Menghadapi Kasus-Kasus Kontemporer).”

${ }^{17}$ Wahyudi, "Peran Politik Perempuan Dalam Persfektif Gender." ${ }^{18}$ Pudji, "Citra Perempuan Dalam Politik."

${ }^{19}$ Zamroni, "Perempuan Dalam Kajian Komunikasi Politik Dan Gender.”
} 


\section{Biography and Background of Amina Wadud's Thoughts}

Amina Wadud's real name is Maria Teasley. He was born in September 1952 in Bethesda, Maryland, United States. She is of AfricanAmerican (black) descent. His father was a Methodist, while his mother was of Arab-African descent. ${ }^{20}$ Wadud also admits not being so close to his father. Thus, he did not have much influence from his father. Then at the age of 20 years, Amina Wadud obtained guidance to convert to Islam. He admits there is an interest in Islam, especially the issue of the concept of justice. ${ }^{21}$ Then in 1972, she recited the creed, and on that day, he named it "thanks giving day." 22

During Wadud's time in education, he was often invited as a guest or speaker of dialogues on gender equality, justice, human rights, and cultural insights. ${ }^{23}$ She was also active in American founding organizations, persistently voiced women in public, and founded "Sister's in Islam" in Malaysia. ${ }^{24}$ Wadud also writes that she has been a widow for more than 30 years with four children. ${ }^{25}$ In her book Inside the Gender Jihad, she writes that her life was a beginning in the fight for human rights and justice for Muslim women in the world. ${ }^{26}$

Amina Wadud, in her work entitled 'Qur'an and Woman: Rereading the Sacred Text From a Woman's Perspective," discusses the Qur'an from its reading of women. The book is based on her

\footnotetext{
${ }^{20}$ Sari Ramadhana, "Penafsiran Gender Amina Waud Dalam Pandangan Akademisi Banjar," 2019, 37.

${ }^{21}$ Dedi Junaedi, "Konsep Dan Penerapan Takwil Muhammad Quraish Shihab Dalam Tafsir Al-Mishbah," Wawasan: Jurnal Ilmiah Agama Dan Sosial Budaya 2, no. 2 (2017): 223-36.

${ }^{22}$ Amina Wadud, "Inside the Gender Jihad: Women's Reform in Islam," Praktyka Teoretyczna, no. 08 (2013): 2.

${ }^{23}$ Nanik Masyruroh, "Analisis Hukum Islam Terhadap Pemikiran Amina Wadud Tentang Kesaksian Wanita" (PhD Thesis, UIN Sunan Ampel Surabaya, 2017), 43-44.

${ }^{24}$ Erlan Muliadi, "Telaah Atas Pemikiran Amina Wadud Muhsin Dalam "Inside the Gender Jihad," QAWWAM 11, no. 2 (2017): 109-20, https://doi.org/10.20414/qawwam.v11i2.741.

${ }^{25}$ Mutrofin, "Kesetaraan Gender Dalam Pandangan Amina Wadud Dan Riffat Hassan," Teosofi: Jurnal Tasawuf Dan Pemikiran Islam 3, no. 1 (June 3, 2013): 234-66, https://doi. org/10.15642/teosofi.2013.3.1.234-266.

${ }^{26}$ Wadud, "Inside the Gender Jihad," vii.
}

experiences as a woman known to widows who always criminalized, including African racists. Departing from her unease, patriarchy culture is too marginalizing for women ${ }^{27}$ and appears female construction as an object or subject. ${ }^{28}$ During the development of the interpretation of the Qur'an, there was no female interference in the process of interpretation. This interpretation shows that men are superior to women. ${ }^{29}$ The interpretation of the verse is not objective but more subjective, were interpreting a verse is more likely what is needed by men and their views and experiences. ${ }^{30}$ Thus, the way it can be done for women's right one-time deconstruction verse of gender.

\section{Hermeneutics of Amina Wadud}

Amina Wadud's way of thinking in interpreting the Qur'an is inseparable from the framework of Fazlur Rahman, a Muslim intellectual who pioneered contextual interpretation. ${ }^{31}$ Amina Wadud's frame of mind in interpreting, she corrects the previous interpretations to convey the implied message contained in verse. The Qur'an is valid all the time, and it offers a practical method to open up the true meaning that corresponds to the development of the times. Therefore, Wadud attempted to use the method of interpretation of "Hermeneutics of the Qur'an." However, to look at more specific issues about equality and justice for women, "Feminist Hermeneutics" is more appropriately named in interpreting the verses of gender justice.

\footnotetext{
${ }^{27}$ M. Rusydi, "Relasi Laki-Laki Dan Perempuan Dalam Al-Qur'an Menurut Amina Wadud," MIQOT: Jurnal Ilmu-Ilmu Keislaman 38, no. 2 (December 9, 2014), https://doi.org/10.30821/miqot. v38i2.60.

${ }^{28}$ Sokhi Huda, "Kontroversi Hak Dan Peran Perempuan Dalam Pemikiran Kontemporer Amina Wadud," Jurnal Urwatul Wutsqo 2, no. 2 (September 2013): 25-44.

${ }^{29}$ Aspandi M, "Hermeneutik Amina Wadud; Upaya Pembacaan Kontekstual Teks Keagamaan," Legitima: Jurnal Hukum Keluarga Islam 1, no. 1 (December 27, 2018): 44-61, https:// doi.org/10.33367/legitima.v1i1.642.

${ }^{30} \mathrm{Ibid}$.

${ }^{31}$ Mutrofin, "Kesetaraan Gender Dalam Pandangan Amina Wadud Dan Riffat Hassan."
} 
In interpreting, Amina here uses three main principles in dismantling gender thinking, namely the principle of tawhid, piety, and caliphate. This principle tells us that the glory of man is not seen from gender but by piety. This principle also confirms that every human being is sent down on earth to be a leader. ${ }^{32}$ Existence of this theory comes from the Wadud hypothesis, which holds that the creation of men and women through the same stage. In his approach, Wadud focuses on one crucial aspect of the "holistic approach." This method has the intention to be able to overcome all parts of the Qur'an while having the aim to overcome the dynamics of the Qur'an between universal and particular. The Qur'an here seeks to establish a universal understanding of moral guidelines. Seeing the Arab situation was very important as the background of the revelation of the Quran with the aim of universal guidelines for Muslims. The development of generations of Muslims should consider how the holy text is limited by time. The existence of context language can make revelation more universally understood and not make Arabic a sacred language. We as Muslims also never suspect that God is not potentially multilingual. Meanwhile, Wadud writes that the term in Arabic refers to gender in expressing against inanimate or living objects, physical and even metaphysical nature, and dimensions. ${ }^{33}$

In the process of finding the meaning of a verse, Wadud uses several methods against verses of the Qur'an to obtain conclusions of the meaning of the text. ${ }^{34}$ See chart below:

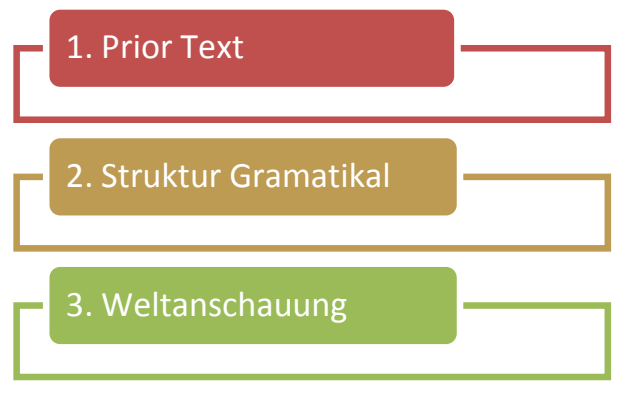

\footnotetext{
${ }^{32}$ Wadud, "Inside the Gender Jihad," 63-64. ${ }^{33}$ Ibid., xii.

${ }^{34}$ Ibid., 3 .
}

The unity of the above three aspects in Wadud's view helps the interpreter find the text's desired intent and reduces the interpreter's subjectivity. ${ }^{35}$ The first step applied by Wadud is to look at the context in which the Qur'an was revealed. Second, look at the grammatical structure or more straightforward composition of the language. Third, look at the substance of the text in the world view. The emphasis of these three aspects is significant to see the varied comparison of women's experiences to be more effective. In Wadud's view here so as not to occur relativism, he asserts that there is a continuing relationship in the text of the Qur'an. Wadud explained that in order for the meaning of the Qur'an to be adequately conveyed, then a guideline must be fixed and understood in the social sphere. Wadud explained that to realize what is the purpose of the Qur'an, and then a guideline must be fixed and understood in the social sphere as the three units above. ${ }^{36}$

In his book "Liberal Islamic Discourse," Charles Guzman explains that Amina Wadud, in researching her dissertation entitled 'Qur'an and Women," has closely related to the historical socio-context of the struggles of AfricanAmerican women that have always been marginalized. ${ }^{37}$ Amina Wadud also said that classical interpretation is written mainly by men, wherein interpreting most is based on the experience and needs of men only. So that the experience of women is negated, and there is no visible opportunity for women to interpret and make commentary on the Qur'an. ${ }^{38}$ At that time, women were still considered second sex, so Wadud believes the emergence of gender inequality because of gender bias towards the

\footnotetext{
${ }^{35}$ Aspandi M, "Hermeneutik Amina Wadud; Upaya Pembacaan Kontekstual Teks Keagamaan," 54.

${ }^{36}$ Wadud, "Inside the Gender Jihad," 5.

${ }^{37}$ Charles Kurzman, Liberal Islam: A Sourcebook (Oxford University Press, 1998); Ramadhana, "Penafsiran Gender Amina Wadud Dalam Pandangan Akademisi Banjar," 42.

${ }^{38}$ Wadud, "Inside the Gender Jihad," 1.
} 
interpretation of the text. ${ }^{39}$

Amina Wadud believes that there is no objective interpretation. He said that, in fact, so far, no scholars have been able to interpret the verses of the Qur'an entirely objectively. Scholars tend to interpret the Qur'an, and this interpretation is only called subjective. Moreover, since the revelation of the Qur'an to the earth, no interpretation is really. So it is no wonder that some scholars have different views on the understanding of a verse in the Qur'an. ${ }^{40}$

\section{Amina Wadud and Qs. An-Nisa:34}

One of the verses commonly interpreted as a pretext for men to have more rights than women is QS. an-Nisa': 34. In this case, Amina Wadud tried to destruct the previous interpretation. Here is the verse:

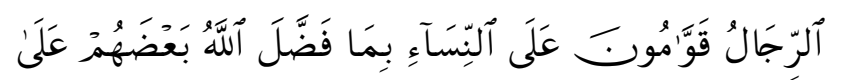




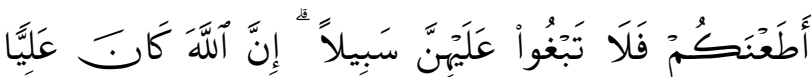

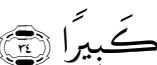

Translate: "Men are in charge of women, because Allah hath made the one of them to excel the other, and because they spend of their property (for the support of women). So good women are the obedient, guarding in secret that which Allah hath guarded. As for those from whom ye fear rebellion, admonish them and banish them to beds apart, and scourge them. Then if they obey you, seek not a way against them. Lo! Allah is ever High, Exalted, Great." 
Above the verse, scholars pay more attention especially the word آلرِّجَالُ قَوَّامُوْنَ عَلَى النَّنَسَاءِ and نُشُوْْزَ so that it becomes two discussions in one verse. Here is the asbab an-nuzul and the interpretation of scholars related to QS. an-Nisa': 34

\begin{tabular}{|c|c|c|c|}
\hline No. & Verse & \multicolumn{2}{|c|}{ Asbab an-Nuzul } \\
\hline 1. & $\begin{array}{l}\text { QS. an-Nisa': } \\
34\end{array}$ & $\begin{array}{l}\text { This verse is } \\
\text { had slapped } \\
\text { Abi Hurairal } \\
\text { the Prophet } \\
\text { came to deli } \\
\text { said, "O my } \\
\text { ment to Sa'i } \\
\text { which He wi }\end{array}$ & $\begin{array}{l}\text { on an incident about the case of Sa'id ibn Rabi' who } \\
\text { e. This event was caused by Habibah Binti Zaid bin } \\
\text { defiance (Nusyuz). However, Habibah complained to } \\
\text { hen Sa'id was given a punishment qișas. However, he } \\
\text { Surah an-Nisa', and said, "This is from Allah," and he } \\
\text { g, "I want one thing, while Allah desires another thing } \\
\text { getter for human." }\end{array}$ \\
\hline No & Scholars & Time & Interpretation \\
\hline 1. & Ibn Katsir & Classical & $\begin{array}{l}\text { Men are the leader, authority, and judge of women and } \\
\text { educators for him if the woman deviates. The male } \\
\text { position is higher than the female, and the male is } \\
\text { considered better than the female because of prophet- } \\
\text { ic degrees played by men. As well as leadership, men } \\
\text { are considered the most important. The Prophet said, } \\
\text { "I will not take any of will not be Happy country gov- } \\
\text { erned by women. }{ }^{42}\end{array}$ \\
\hline 2. & $\begin{array}{l}\text { Ar-Razi (Mafatih } \\
\text { (al-Ghaib }\end{array}$ & Classical & $\begin{array}{l}\text { He means "qawwam," leader for women. It means the } \\
\text { responsibility of men to women ranging from science } \\
\text { to security. Because in general, men are more power- } \\
\text { ful and deserve to be leaders under challenging jobs. } \\
\text { For example, in general, the role of men is complex } \\
\text { and memorable, including Nabi, ulama, imam, adzan, } \\
\text { khutbah, and the most significant authority is in the } \\
\text { realm of marriage, such as; divorce, reference, and } \\
\text { head of the family. }{ }^{43}\end{array}$ \\
\hline
\end{tabular}

\footnotetext{
${ }^{41}$ See Al-Wahidi, Asbab Al-Nuzul Qur'an (CD Maktabah al-Shamilah), Vol 1, 100; Rahmawati Hunawa, "Kedudukan Suami-Istri (Kajian Surah An-Nisa' [4]: 34)," Potret Pemikiran 22, No. 1 (July 1, 2018), Https://Doi.Org/10.30984/Pp.V22i1.758.

${ }^{42}$ Muhammad Nasib Rifa'i, Kemudahan Dari Allah: Ringkasan Tafsir Ibnu Katsir (Jakarta: Gema Insani, 1999). 650

${ }^{43}$ see Fakhr al-Din Mahmud Ibn Umar Ibn Al-Husain Ibn al-Hasan Ibn Ali al-Tamimi al-Burn al-Razi al-Shafi'i, Mafatih al-Ghaib (Tafsir Al-Kabir), vol. 9-10 (Libanon: Dar Al- Pole al-Ilmiyyah, 2009), 159-160, In Irsyadunnas, "Tafsir Ayat-Ayat Gender Ala Amina Wadud Perspektif Hermeneutika Gadamer," 134.
} 


\begin{tabular}{|l|l|l|l|}
\hline 3. & Jawad Mughni- \\
yah & (Al-Kashif) & $\begin{array}{l}\text { This verse does not mean to preach that men have a } \\
\text { position higher than women, which produces an un- } \\
\text { derstanding that must be obedient is female, not male. } \\
\text { Not only that, but this verse is also often understood } \\
\text { that men as leaders mean having higher positions than } \\
\text { females. Ayat is only addressed to men as a husband } \\
\text { for women. This verse is only for the realm of the } \\
\text { household because the husband has a role as a priest } \\
\text { for a wife. It also does not mean the leader is a ruler } \\
\text { or dictator. }\end{array}$ \\
\hline
\end{tabular}

If understood only based on the text, the verse above, of course, interpreted male leaders for women. Classical and modern scholars widely find this interpretation. Tafsir like this is usually influenced by the pre-understanding that can shape one's thinking because of environmental factors, community culture, community systems, science, and technology. ${ }^{45}$

Sahiron criticized classical interpretations such as Ibn Katsir that the above phrase looks very gender-biased. As in the sentence "ar-rajulu afdhalu min al-mar'ah (men are more mainstream than women), and "ar-rajulu khairun min al-mar'ah" (men better women), for this basis, women should not be leaders in public lands. ${ }^{46}$ If analyzed, the tendency of classical interpretation is more textual and historical. The concept of interpretation as the text speaks regardless of context. The classical scholars understand that it seems that God bestows excess on men to lead and obedience to women. Then, the meaning of obedience is criticized by Amina Wadud because the word "qanitat" does not mean a woman who obeys her husband but rather a good woman. ${ }^{47}$

Like Wadud, the word "ar-rijalu qawwamuna "ala nisa" is not enough when interpreted as a couple only. The nature of this word occurs when two conditions take place - the first is the right to take precedence over others and give women a living. However, if one of the conditions is not carried out, causing the male is considered a failure and omits the qawwam referred to as female. ${ }^{48}$ However, it is precisely the assumption that the meaning of this word is different from the interpretation of the classical period that means "qawwam" leader for women. Among them is ar-Razi's opinion, which explains that the obligation of men over women includes education to a sense of security. ${ }^{49}$

About this verse, the word qanitat is often interpreted as a good woman then shown to the word "obedient," which is interpreted as "obedient to the husband." So wives here who disobey the husband are considered nusyuz, then given punishment, give advice, sleep apart, and scourge them. Wadud believes in a settlement between husband and wife, whereas concerning the context of the Qur'an, this word is used to men as well. Wadud added Sayyid Qutb, who Qutb, and that this word can

\footnotetext{
${ }^{44}$ See Muhammad Jawad, Mughniyyah Interpretation al-Kasyif, Ed. 1, Vol. II (Beirut: Dar Al-‘Ilm Li Al-Malayin, 1968), 314, In Sofia Rosdanila Andri, “Argumen Penafsiran Tekstualis versus Kontekstualis Tentang Kepemimpinan Perempuan,” Refleksi 13, no. 6 (April 21, 2014): 761-78, https://doi.org/10.15408/ref.v13i6.999.

${ }^{45}$ Sahiron Syamsuddin, "Hermeneutika Dan Pengembangan Ulumul Qur'an,” 2009, 145.

${ }^{46}$ Ibid., 146.

${ }^{47}$ Andri, "Argumen Penafsiran Tekstualis versus Kontekstualis Tentang Kepemimpinan Perempuan," 769.

${ }^{48}$ Wadud, "Inside the Gender Jihad," 70-71.

${ }^{49}$ Irsyadunnas, "Tafsir Ayat-Ayat Gender Ala Amina Wadud Perspektif Hermeneutika Gadamer,” 134.
} 
show a personal emotional response instead of external ones that follow the commands of the word obey and the rest. Wadud also explained to pay more attention to the word nusyuz which is, not only directed at women, although it has long been defined differently. However, when applied to wives, then this term is often defined as disobedience to the husband. Other opinions also say this verse indicates that the wife must obey the husband using obedience.

Wadud explained that because the Qur'an uses the word nusyuz not only for women, it cannot mean "obedience to the husband." Wadud added the opinion of Sayyid Qutb, who explained that this is a matter of the state of disorder between married couples. In this case, the Qur'an has been the solution to every husband and wife's intercession. For example, in an-Nisa': 34: advise through the help of the mediators. Then, an-Nisa': 35 explains that if open discussion fails, then a more drastic solution is separation or as the last step of the permitted courge. Then, Wadud emphasized the things to note, although domestic disputes are also not finished with the order of solutions suggested by the state and recommended by the Qur'an. The scourge should not be the last resort because it is not what the Religion of Islam wants. ${ }^{50}$

As for the word views from different circles. Ibn Taimiyyah that nusyuz was a defiance of the husband's orders, including when refused if invited to bed or out of the house without her husband's permission and everything that did not follow her husband's orders. ${ }^{51}$ In contrast to Rasyid Ridha, he rejected the presumption of legitimizing women with the term Nusyuz. He said the blow was merely a

\footnotetext{
${ }^{50}$ Amina Wadud., Qur'an and Women, 74-75

${ }^{51}$ Ibnu Taimiyyah, Majmu Fatawa Tentang Nikah, translated by Abu Fahmi Huadi dan Syamsuri Inyati (Jakarta: Pustaka Azam, 2001), 242; Mushodiqin, "Studi Pemikiran Amina Wadud Muhsin Tentang Penyelesaian Nusyuz Yang Dilakukan Oleh Istri: Analisis Dari Perspektif Tafsir QS. an-Nisa': 34" (undergraduate, IAIN Walisongo, 2008), http://eprints. walisongo.ac.id/11793/.
}

substitute for bitter medicine done when the wife completely this complying, rebelling violently, and arguing. The punch in question here is the latest blow after the option afterward did not deter the wife. However, this blow should not use tools or sharp objects that damage the body or injure the wife. It should not hurt women physically, especially their wives. However, if the husband continues to do a brutal and violent blow that can hurt the wife, this is considered to be included in domestic violence. ${ }^{52}$

The same opinion was signaled by Sinta Nuriyyah, who explained that nusyuz should be understood correctly. QS. an-Nisa': 34 is used as an excuse to commit violence against wives. According to him, this nusyuz case should be done if it turns out to bring good in the household and does not harm his partner. However, according to him, the wife's beating will cause a harmful psychological impact primarily if other parties or families know the time of the incident, especially their children. Thus, in such cases, beatings should be avoided. ${ }^{53}$

While Amina Wadud explained again related to the verse that is only understood textually only. In addition, he reinterpreted the words "qanitat" meaning 'good woman,' and "nusyuz," which is understood based on two keys, namely gender relations and the concept of obedience. Furthermore, the word "fadhdala" (virtue), talking about the excess of degrees between women and men at the command of Allah Almighty. More clearly, there is a reference of the Qur'an that distinguishes the portion of inheritance rights to men greater than women, contained in QS. anNisa': $7 .{ }^{54}$ In this interpretation, Amina Wadud

\footnotetext{
${ }^{52}$ Ali Yusuf as-Subki, Fiqh Keluarga: Pedoman Berkeluarga dalam Islam, translated by Nur Khozin (Jakarta: Amzah, 2010), 314; Mughniatul Ilma, "Kontekstualisasi Konsep Nusyuz Di Indonesia," Tribakti: Jurnal Pemikiran Keislaman 30, no. 1 (January 31, 2019): 47-74, https://doi.org/10.33367/tribakti.v30i1.661.

${ }^{53}$ Liatun Khasanah, "Konsep Nusyuz Menurut Kompilasi Hukum Islam (Perspektif keadilan gender)" (skripsi, IAIN Purwokerto, 2017), 23, http://repository.iainpurwokerto.ac.id/2042/.

${ }^{54}$ Amina Wadud, Qur'an and Women, 70.
} 
considers the word "qiwamah" a very concerning topic for families in the social sphere. He focused the word qiwamah on various spheres, spiritual, moral, and psychological. When understood at a glance, the perspective of the word qiwamah ${ }^{55}$ will cause destructive interests and not nurture. So is the meaning of "nusyuz," which is still widely understood as the ability to hit the wife willingly. Therefore it is crucial to know the original meaning of what the Qur'an is talking about.

\section{Implications of Amina Wadud's Thinking in Indonesia}

The implications of Amina Wadud's thinking in Indonesia can measure through her visit to Indonesia and the dissemination of her work, and the study of her thinking.

First, Amina Wadud had been to Indonesia as a speaker in one of the events organized by Rumah Kitab, which pays attention to discrimination caused by the interpretation of religious texts. This event was also attended by Muslim scholars such as Nur Rofiah and Ulil Abshar Abdalla. ${ }^{56}$ The study of gender studies Amina Wadud can also be seen from how her work in Indonesia directly. Like some of her famous works have been widely distributed, namely 'Qur'an and Women: Rereading the Sacred Text From a Women's Perspective" published in New York: Oxford University Press, 1999. Another work titled "Inside the Gender Jihad Women's Reform in Islam" was published in New York: Oxford University in 2006. The book shave been widely sold through a variety of online shop and offline shop applications. In addition, the author also found his book in the form of an e-book. With the ease of accessing his writings, it is not an excuse for us not to learn more deeply, including matters related to gender and the Qur'an.

\footnotetext{
${ }^{55}$ Ibid., 73

56"Mengenal Amina Wadud, Bintang Rock Feminisme Islam," accessed July 11, 2021, https://magdalene.co/story/mengenalamina-wadud-bintang-rock-feminisme-islam.
}

The study of Amina Wadud's thinking is still widely used as a material study of a study related to gender and the Qur'an. This figure became a discussion of material in academics, such as in the courses of the Qur'an Hadith and Gender, Contemporary Interpretation Thought, and Hermeneutics. In addition, many students participated in conducting research related to the thinking or methodology of gender ala Amina Wadud in the academics of the Islamic State of Indonesia, many lecturers and professors who conduct research in its entirety, namely "Interpretation of the Qur'an that is GenderSensitive: Critical Study of The Thinking of Amina Wadud Muhsin, in the Study of Contemporary Interpretation" by Abdul Mustaqim in Yogyakarta: TH Press, in 2006. Another work by Ahmad Baidlowi with the title "Feminist Commentary: Study of The Thinking of Amina Wadud and Nasr Hamid Abu Zayd" thesis in 2009. Research in the journal titled "Tafsir gender verses Ala Amina Wadud Prespektif Hermeneutics Gadamer" by Irsyadunnas musawwa journal in 2015. Related to the contribution of Wadud study has been widely done and researched by Indonesian Muslims, either scholars or students.

Secondly, the emergence of Indonesian Muslim scholars interested and dig deeper about the subordination of verses that tend to be gender-biased. They have great concern for gender verses. Part of their thinking has something in common with Wadud. It can say that their thinking is a development of Wadud's thinking or a reinterpretation with a feminist tone. As for the figures of the shops, among others, Musdah Mulia, Nasaruddin Umar, and Husein Muhammad.

Husein Muhammad is one of the male Muslim feminists in Indonesia. He has the same opinion as Wadud that Husein recognizes one of the roots of the problem of gender equality lies in the biased interpretation of the Qur'an and Hadith. Husein Muhammad did various ways to fight for women from the order that he thought 
was caused by religious thought, culture, and patriarchy ideology. Husein admits that his role in pesantren's location has concerns about gender equality in traditional pesantren. ${ }^{57} \mathrm{His}$ effort is also not far from very productive things and teaching the yellow book to his students. All efforts made by Husein have the same principle rights as Amina Wadud, namely Tawhid. Thus, if tawhid takes precedence, then all roles can be performed by both men and women themselves. Thus, the principle of tawhid becomes very important, especially in the context of equality and justice, apart from Husein Muhammad, who has a background in pesantren and focuses on his work in traditional pesantren. ${ }^{58}$

The results of Nasruddin Umar's study explained that, in the Qur'an, there is some differences term that needs to be distinguished. These differences are like gender and sex categories. However, this is still an obscured thing. In its interpretation, ${ }^{59}$ the approach used is to collect verses of the Quran with the phrase mudzakar muannats as the term most often used in the Qur'an. Nasaruddin Umar has similarities with Amina Wadud to analyze the meaning of a verse, Such as using the approach ulumul Qur'an, namely, Asbabun Nuzul (macro and micro), reasonable, as well as makiyyah and madaniyyah. The approach used by Nasaruddin here borrows Fazlurrahman's double movement, where the Fazlurrahman approach theory is used by Amina Wadud in terms of the context of the present and

\footnotetext{
${ }^{57}$ Yusuf Rahman, "Feminist Kyai, K.H. Husein Muhammad: The Feminist Interpretation on Gendered Verses and the Qur'ānBased Activism," Al-Jami'ah: Journal of Islamic Studies 55, no. 2 (December 15, 2017): 293-326, https://doi.org/10.14421/ ajis.2017.552.293-326.

${ }^{58}$ Nasitotul Janah, "Telaah Buku Argumentasi Kesetaraan Gender Perspektif Al-Qur'an Karya Nasaruddin Umar,” Sawwa: Jurnal Studi Gender 12, no. 2 (April 30, 2017):

${ }^{59}$ Ai Nurnira Kholifah, "Perempuan dan pendidikan dalam kajian Tafsir Feminis: Studi analisis terhadap pemikiran KH. Husein Muhammad" (diploma, UIN Sunan Gunung Djati Bandung, 2017), http://digilib.uinsgd.ac.id/22630/.
}

the time when the Qur'an was revealed. ${ }^{60}$

Furthermore, Nur Rofiah has similarities in his argument with Wadud. Although the similarity of this argument, there is no evidence of a direct relationship between the two. Regardless, Nur Rofiah elaborates a lot on justice for women against violence, the reinterpretation of some religious concepts about women, and the theology of justice for women. This book is based on many experiences of female victims in the domestic realm. Overall the book has the same interpretation as Amina Wadud. Nur Rofiah writes that the issue of discrimination against women tends to be ignored. This issue of discrimination departs from the first assumption that religious understanding is only based on textuality, which causes the verses of the Qur'an to be understood piece, causing the meaning of justice that so the basis of the entire verse has faded. Second, the interpretation of religious texts has been dominated by the experience of men, causing women's condition to be neglected. Third, ignoring the socio-historical conditions that occur today, when the present condition becomes essential because it could allow the birth of different textual meanings of the same verse. ${ }^{61}$

In addition to having similar interpretations with Wadud, Nur Rofiah also wrote that the position ofmen over women is higher as breadwinner. However, it is not uncommon for facts in society to differ from before. In addition, there is also the role of women as single parents or sole breadwinners in the family. More than that, women can do too. Thus, men as breadwinners are only the nature of society.

\section{Conclusion}

Interpretation of QS. an-Nisa': 34 cannot be understood only in the text that refers to the interpretation of classical times - related to this

\footnotetext{
${ }^{60}$ Janah, "Telaah Buku Argumentasi Kesetaraan Gender Perspektif Al-Qur'an Karya Nasaruddin Umar.

${ }^{61}$ Nur Rofiah, Memecah Kebisuan - Respon NU: Agama Mendengar Suara Perempuan Korban Kekerasan Demi keadilan (Komnas Perempuan, 2010), 104.
} 
letter the previous scholars used as the legality of male leadership over women with various interpretations. However, Wadud firmly believed that the understanding could not be absolute by following the changing times that are growing. Thus, he refused and explained the reinterpretation of gender bias using his hermeneutic approach that prioritizes the principle of tawhid as explained in the word qawwam that cannot be interpreted solely as a husband and wife relationship only. However, it must be understood in a broader context by the community itself. In addition, in this verse, there is also the concept of nusyuz, which is widely understood narrowly, which will instead assume the legitimacy of women with the term nusyuz. Even if the husband has to hit because of insubordination by the wife, he still should not intend to kill while using sharp objects to hurt him. Because if that happens, it means that this case goes into the KDRT.

The thought used by Wadud attracted much controversy from the beginning, who supported and rejected it. Including in Indonesia, Amina Wadud's thinking has significant support and influence. It is seen from the many visits she has to Indonesia because of the academic invitation to voice about gender, the number of studies in the scientific literature even used as a feminist figure referred to when writing about gender. The development of her thoughts by Muslim scholars in Indonesia such as KH. Husein Muhammad championed the existence of women in the realm of order through the yellow book. So did Mrs. Sinta Nuriyyah who founded PUAN. Then Nasaruddin Umar wrote many of his works on gender equality PerspektiveQur'an and Nur Rofi'ah. They managed to establish the KGI community and filled many public forum events related to justice. Overall, these Muslim scholars say it has the same reason by Wadud that we urgently need to reread the verses of gender bias by synchronizing the context in this era.

\section{References}

Andri, Sofia Rosdanila. "Argumen Penafsiran Tekstualis Versus Kontekstualis Tentang Kepemimpinan Perempuan." Refleksi 13, No. 6 (April 21, 2014): 761-78. Https:// Doi.Org/10.15408/Ref.V13i6.999.

Arsal, Arsal. "Menangkap Pesan-Pesan Hukum Dalam Al-Qur'an (Alternatif Dan Solutif Penggunaan Metode Tafsir Kontekstual Dalam Menghadapi KasusKasus Kontemporer)." ALHURRIYAH: Jurnal Hukum Islam 1, No. 1 (2016): $1-14$.

Huda, Sokhi. "Kontroversi Hak Dan Peran Perempuan Dalam Pemikiran Kontemporer Amina Wadud." Jurnal Urwatul Wutsqo 2, No. 2 (September 2013): 25-44.

Ilma, Mughniatul. "Kontekstualisasi Konsep Nusyuz Di Indonesia." Tribakti: Jurnal Pemikiran Keislaman 30, No. 1 (January 31, 2019): 47-74. Https://Doi. Org/10.33367/Tribakti.V30i1.661.

Irsyadunnas, Irsyadunnas. "Tafsir Ayat-Ayat

Gender Ala Amina Wadud Perspektif Hermeneutika Gadamer." Musãwa Jurnal Studi Gender Dan Islam 14, No. 2 (2015): 123-42.

Janah, Nasitotul. "Telaah Buku Argumentasi Kesetaraan Gender Perspektif Al-Qur'an Karya Nasaruddin Umar." Sawwa: Jurnal Studi Gender 12, No. 2 (April 30, 2017): 167-86. Https://Doi.Org/10.21580/ Sa.V12i2.1707.

Junaedi, Dedi. “Konsep Dan Penerapan Takwil Muhammad Quraish Shihab Dalam Tafsir Al-Mishbah." Wawasan: Jurnal Ilmiah Agama Dan Sosial Budaya 2, No. 2 (2017): 223-36.

Khasanah, Liatun. "Konsep Nusyuz Menurut Kompilasi Hukum Islam (Perspektif Keadilan Gender)." Skripsi, IAIN Purwokerto, 2017. Http://Repository. Iainpurwokerto.Ac.Id/2042/. 
Kholifah, Ai Nurnira. "Perempuan Dan Pendidikan Dalam Kajian Tafsir Feminis: Studi Analisis Terhadap Pemikiran KH. Husein Muhammad." Diploma, UIN Sunan Gunung Djati Bandung, 2017. Http://Digilib.Uinsgd.Ac.Id/22630/.

Komariah, Siti. "Perubahan Peranan Wanita Sunda: Studi Kasus Di Kota Bandung." TEMALI: Jurnal Pembangunan Sosial 2, No. 2 (2019): 354-84.

Kurzman, Charles. Liberal Islam: A Sourcebook. Oxford University Press, 1998.

M, Aspandi. "Hermeneutik Amina Wadud; Upaya Pembacaan Kontekstual Teks Keagamaan.” Legitima : Jurnal Hukum Keluarga Islam 1, No. 1 (December 27, 2018): 44-61. Https://Doi.Org/10.33367/ Legitima.V1i1.642.

Magdalena, R. "Kedudukan Perempuan Dalam

Perjalanan Sejarah (Studi Tentang Kedudukan Perempuan Dalam Masyarakat Islam)." Harakat An-Nisa: Jurnal Studi Gender Dan Anak 2, No. 01 (2018).

Masyruroh, Nanik. "Analisis Hukum Islam

Terhadap Pemikiran Amina Wadud Tentang Kesaksian Wanita." Phd Thesis, UIN Sunan Ampel Surabaya, 2017.

"Mengenal Amina Wadud, Bintang Rock Feminisme Islam." Accessed July 11, 2021. Https://Magdalene.Co/Story/ Mengenal-Amina-Wadud-Bintang-RockFeminisme-Islam.

Muliadi, Erlan. "Telaah Atas Pemikiran Amina Wadud Muhsin Dalam "Inside The Gender Jihad." $Q A W W A M$ 11, No. 2 (2017): 10920. Https://Doi.Org/10.20414/Qawwam. V11i2.741.

Mushodiqin, Mushodiqin. "Studi Pemikiran Amina Wadud Muhsin Tentang Penyelesaian Nusyuz Yang Dilakukan Oleh Istri : Analisis Dari Perspektif Tafsir QS. An-Nisa' : 34." Undergraduate, IAIN Walisongo, 2008. Http://Eprints. Walisongo.Ac.Id/11793/.
Mutrofin, Mutrofin. “Kesetaraan Gender Dalam Pandangan Amina Wadud Dan Riffat Hassan." Teosofi: Jurnal Tasawuf Dan Pemikiran Islam 3, No. 1 (June 3, 2013): 234-66. Https://Doi.Org/10.15642/ Teosofi.2013.3.1.234-266.

Pudji, Tri Marhaeni. "Citra Perempuan Dalam Politik." Yinyang: Jurnal Studi Islam Gender Dan Anak 3, No. 1 (2008): 3-16. Rahman, Yusuf. "Feminist Kyai, K.H. Husein Muhammad: The Feminist Interpretation On Gendered Verses And The Qur'ānBased Activism." Al-Jami'ah: Journal Of Islamic Studies 55, No. 2 (December 15, 2017): 293-326. Https://Doi. Org/10.14421/Ajis.2017.552.293-326.

Ramadhana, Sari. "Penafsiran Gender Amina Waud Dalam Pandangan Akademisi Banjar," 2019.

Rifa'i, Muhammad Nasib. Kemudahan Dari Allah: Ringkasan Tafsir Ibnu Katsir. Gema Insani, 1999.

Rini, Rini. "Kontekstualisasi Tafsir Feminis Amina Wadud Pada Masyarakat Islam Di Indonesia." FOKUS Jurnal Kajian Keislaman Dan Kemasyarakatan 4, No. 1 (2019): 67-90.

Rofiah, Nur. Memecah Kebisuan - Respon NU: Agama Mendengar Suara Perempuan Korban Kekerasan Demi Keadilan. Komnas Perempuan, 2010.

Rusydi, M. "Relasi Laki-Laki Dan Perempuan Dalam A1-Qur'an Menurut Amina Wadud." MIQOT: Jurnal Ilmu-Ilmu Keislaman 38, No. 2 (December 9, 2014). Https://Doi.Org/10.30821/Miqot. V38i2.60.

Shihab, M. Quraish. Perempuan: Dari Cinta Sampai Seks, Dari Nikah Mut'ah Sampai Nikah Sunnah, Dari Bias Lama Sampai Bias Baru. Jakarta: Lentera Hati Group, 2010.

Syahbana, Ali. "Studi Komparatif Pemikiran Ibnu Hazm Dan Ibnu Qudamah Tentang 
Hukum Penyusuan (Raḍā'ah).” Ph.D

Thesis, IAIN Palangka Raya, 2018.

Syamsuddin, Sahiron. "Hermeneutika Dan

Pengembangan Ulumul Qur'an,” 2009.

Ulum, Khozainul. "Amina Wadud Muhsin Dan

Pemikirannya Tentang Poligami." Al Hikmah:

Jurnal Studi Keislaman 7, No. 1 (2017).

Wadud, Amina. "Inside The Gender Jihad:

Women's Reform In Islam." Praktyka

Teoretyczna, No. 08 (2013): 249-62.

Wahyudi, Very. "Peran Politik Perempuan Dalam

Persfektif Gender." Politea: Jurnal Politik

Islam 1, No. 1 (2018): 63-83.
Warits, Abd. "Menggagas Fiqh Perempuan: Membangun Kekuatan Hukum Bagi Perempuan (Telaah Kritis Atas Pemikiran Kh. Husein Muhammad)." In Proceedings Of Annual Conference For Muslim Scholars, 486-503, 2017.

Zainudin, Muhammad, And Ismail Maisaroh. "Posisi Wanita Dalam Sistem Politik Islam." MIMBAR: Jurnal Sosial Dan Pembangunan 21, No. 2 (2005): 178-95. Zamroni, Mohammad. "Perempuan Dalam Kajian Komunikasi Politik Dan Gender." Jurnal Dakwah 14, No. 1 (2013): 103-32. 